\title{
Disturbance of cytokine networks in Sjögren's syndrome
}

\author{
Pierre Youinou ${ }^{1,2 *}$ and Jacques-Olivier Pers ${ }^{1,2}$
}

\begin{abstract}
The difficulty in predicting the consequences of interactions between different cytokine networks has increased with the expansion of the Thelper (Th) cell universe and the discovery of numerous B lymphocyte-derived cytokines. Consequently, it is now difficult to conceptualize a straightforward view of the contribution of these disturbances to the pathogenesis of primary Sjögren's syndrome (SS). Th1 cells, which produce interferon- $\gamma$ and IL-2, and Th17 cells, which make IL-17 and TNF-a, have been cast in the leading roles of the play. However, the complex role of T-cell subsets in SS is accentuated by the reciprocal effects of Th17 cells and regulatory $T$ cells found in salivary glands of SS patients. Furthermore, B lymphocyte polarization into type-1 B effector (Be1) and Be2 cells and B-cell modulating factors of the TNF family, most notably the B-cell-activating factor (BAFF), and their prominent role in SS are additional complicating factors. Whereas Th17 cells orchestrate autoreactive germinal centers, local BAFF would repress the generation of Th17 cells. Such new insights into interconnected cytokines in primary SS may lead to new treatments for these patients.
\end{abstract}

\section{Introduction}

Autoimmune epithelitis [1], designated Sjögren's syndrome (SS), primarily affects the lacrimal and salivary glands (SGs), the destruction of which results in xerophthalmia and xerostomia. Regardless of whether this condition presents alone as primary SS or associated with other connective tissue diseases as secondary SS [2], the epithelial structures of the secretory organs are wrapped in a sheath of lymphocytes. These aggregates are

*Correspondence: youinou@univ-brest.fr

"Research Unit"Immunology and Pathology" at the European University of Brittany, Brest, 29609, France

Full list of author information is available at the end of the article predominated by $\mathrm{T}$ lymphocytes, most of which are $\mathrm{CD} 4+$ rather than the CD8+ $\mathrm{T}$ lineage [3]. We [4] and others [5-7] have also described germinal center (GC)like structures of $\mathrm{B}$ cells (Figure 1) infiltrating exocrine tissues.

Several contradictory hypotheses have been forwarded to resolve the complexity of the syndrome [8]. The continuing progress in discovering lymphocyte subsets and the lengthening list of cytokines involved, together with how they are affected in SS, has further fuelled the debate on SS pathogenesis. This has been extended to include whether excessive production of cytokines might contribute to clinical symptoms of SS, such as fever, arthralgia and long-term asthenia.

CD4+ T helper (Th) lymphocytes have long been known to be distributed into Th1 and Th2 cells, based on distinct cytokine patterns [9]. Imbalances between type-1 cytokine-producing Th1 cells and type- 2 cytokineproducing Th 2 cells have been considered as predisposing to autoimmunity. At the time of their seminal discovery, however, Mosmann and Coffman [10] predicted that more Th-cell subsets exist, and indeed numerous Th cell lineages have since been identified. In particular, Th17 cells were described and IL-17 acknowledged as a prime representative of the new generation of proinflammatory cytokines [11]. Concomitantly, regulatory $\mathrm{T}$ (Treg) cells were identified as a unique population of Th cells that restrain excessive activation of effector lymphocytes [12] and maintain $\mathrm{T}$ - and B-cell tolerance to self antigens.

Despite much progress, controversy over which set(s) of lymphocytes and group(s) of cytokines initiate SS pathogenesis persists. In the past, $\mathrm{T}$ cells have been claimed to be capable of initiating autoimmunity on their own, with B cells confined to antibody production. Nevertheless, the failure of T-cell-directed therapies in treating such patients has raised doubts about a dominant role for $\mathrm{T}$ lymphocytes in SS. This observation, made against increased recognition of the role of B lymphocytes in diseases and the efficacy of B-cell-depleting agents [13], sparked interest in whether B cells play some role in the pathogenesis of SS [14]. Despite the dogma that they are instructed by $\mathrm{T}$ cells, compelling evidence has emerged for autonomous roles for B cells, including 


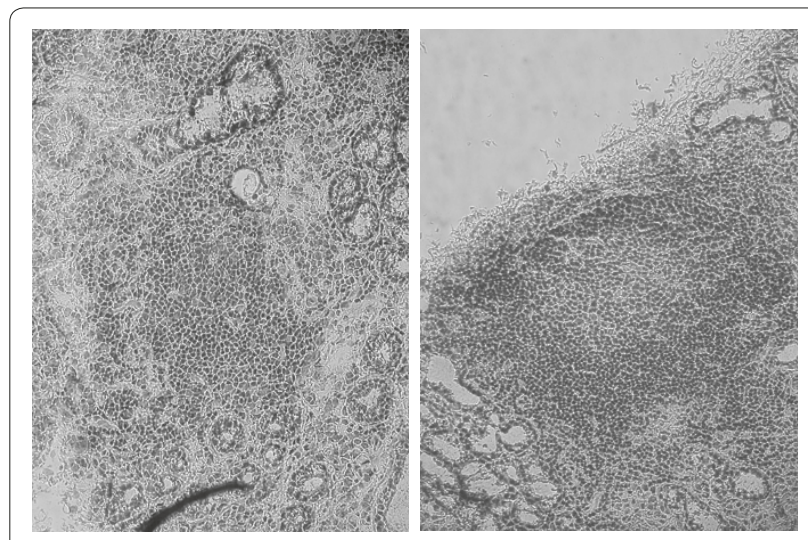

Figure 1. Pathological changes in the salivary glands of patients with primary Sjögren's syndrome. Left: toluidine blue staining unveils infiltrates of mononuclear cells corresponding to T lymphocytes $(\times 16)$. Right: B cells forming an ectopic germinal center $(\times 10)$.

the production of cytokines [15]. Accordingly, our current interpretation of cytokine-secreting B-cell subsets stems from the Th cell paradigm. Regulatory B (Breg) cells, recently described in humans [16], do exert regulatory effects through the production of cytokines. Furthermore, B-cell activation of the TNF family (for example, by B-cell-activating factor (BAFF), also known as B-lymphocyte stimulator (BLyS), and a proliferationinducing ligand (APRIL)) has further substantiated the concept of a notable role for B-cell cytokines in the pathogenesis of SS [17].

The impact of abnormal cytokine production in this disease has attracted considerable attention [18]. Whilst the effect of a cytokine on one lymphocyte subset in SS can be discerned, it has become a challenge to understand how the interaction between several interconnected networks of cytokines impact on so many different cell populations. The concept that the interplay of cytokineproducing $\mathrm{T}$ and $\mathrm{B}$ cells shifts the balance towards autoreactive $\mathrm{T}$ and $\mathrm{B}$ lymphocytes has been questioned. Recent findings on the pathogenesis of SS are beneficial at a time when cytokine-directed therapies are being tested for the treatment of inflammatory diseases. However, it remains highly complex to ascribe different symptoms to just a single cytokine.

\section{T-cell cytokines}

\section{The polarized Th cell paradigm}

Upon T-cell activation, the cytokine milieu dictates Th cell polarization. Thus, IFN- $\gamma$ and IL-12 engage the T box transcription factor, referred to as Tbet, and the signal transducer and activator of transcription (Stat)-4, to transform naïve CD4+ T cells into Th1 lymphocytes. The latter cells are involved in the response to intracellular pathogens, thus inducing the production of IFN- $\gamma$ and TNF- $\alpha$, but not IL-4 and IL-13. In contrast, IL-2 and IL-7 cause the binding of a specific transcription factor to the WGATAR nucleotide consensus sequence (GATA-3). This promotion polarizes naïve $\mathrm{T}$ cells towards $\mathrm{Th} 2$ lymphocytes. The latter cells are committed to the elimination of extracellular pathogens, thus favoring the production of IL-4 and IL-13. Undoubtedly, GATA-3 represents the master transcription factor for Th2 differentiation. Although the two groups of cytokines are mutually inhibitory, IFN- $\gamma$ opposes inflammation in certain disease settings, and IL-4 enhances IL-12 production by macrophages, which in turn favors Th1 polarization of naïve Th lymphocytes. Whereas uncontrolled Th1 cells determine autoimmune states, imbalances in Th2 cells lead to allergic disorders. However, were this binary paradigm to be as presumed, no autoimmune traits should emerge in a proportion of patients with excessive Th2 cells [19].

Patients with SS have long been thought to suffer from a Th1-mediated condition. Such interpretation was supported by high levels of IFN- $\gamma$ in serum [20] and a predominance of Th1 over Th2 cells in blood [21]. In addition, $\mathrm{T}$ cells containing mRNA for IFN- $\gamma$ [22] and Stat-1 have been found in the SGs of patients with SS [23]. In fact, the contribution of each Th subset to SS and their interconnections are more subtle than suggested by the earliest data. In this context, for Th1 cells to underpin SS pathogenesis, one must verify that the activity of Th1 cells is decreased in the blood of patients, while increased in their SGs [24]. Furthermore, the cytokine pattern may shift from Th1 to Th2 as the immunopathological lesions progress, as postulated by Moutsopoulos' group [25]. Supporting their hypothesis, they made the valuable observation that IFN- $\gamma$ expression is associated with a high-grade infiltrate of the SGs, whereas a low-grade infiltrate is instead accompanied by a type- 2 response.

\section{The expanding universe of Th cell subsets Th17 cells}

Inevitably, the role of Th1 and Th2 cells in SS, gleaned from studies of cultured cells and from observations of SS patients, have become contradictory. These discrepancies were resolved by the discovery of IL-23, after which it was determined that abnormalities first ascribed to Th1 cells were instead engendered by Th17 cells, named after their IL-17 cytokine signature [11,26-29]. Th17 cells produce a family of cytokines from IL-17A through IL17F, and, to a lesser extent, TNF- $\alpha$ and IL-22 [11]. Although IL-17 and IL-22 are structurally similar, they bind to distinct receptors and take part in separate intracellular pathways. Furthermore, in contrast to IL-17, IL-22 exerts minor proinflammatory effects, and, under certain circumstances, even protects from autoimmune 
outcomes. Th17 cells are primed by the association of IL6 with either IL-1 or IL-21 via the orphan retinoid nuclear receptor $\gamma \mathrm{t}$, but neither Tbet nor GATA-3. IL-21, a member of the IL-2 family, collaborates with dendritic cell (DC)-derived transforming growth factor (TGF) $\beta$ to amplify the tendency to Th17 cell differentiation and induce these lymphocytes to express receptors for IL-23. The latter cytokine is required for the maintenance of Th17 [30,31]. It is interesting that, at least in mice, Th17 lymphocytes can also function as B-cell helpers [32]. They induce a pronounced antibody response, with preferential immunoglobulin (Ig) class switch to IgG2a and IgG3 for IL-17, and to IgG1 and IgG2b for IL-21. These results establish that Th17 cells are crucial in GC formation.

In line with the mouse data, high serum [33] and saliva [34] levels of IL-17 have been reported in SS patients. In addition, their SGs exhibit a predominance of IL-17containing cells within the inflammatory lesions [27], consistent with the production of IL-17 by ductal epithelial cells. Further work on SGs detected TGF- $\beta$, IL- 6 and IL-23, all requisite promoters of Th17 differentiation [31]. These findings add credence to the view that Th17 cells are possible drivers of the persistent inflammatory response in the SGs of patients with primary SS.

\section{Regulatory T cells}

An exciting aspect of homeostasis of the Th17 cells is their reciprocal relationship with Treg cells. However, there is as yet no universal consensus on their definition. They were originally identified by high membrane levels of CD25. Subsequent studies indicated that this prerequisite for identifying Treg cells did not fit the observation that $\mathrm{CD} 25-\mathrm{CD} 4+\mathrm{T}$ cells exert as many regulatory functions as CD25+CD4+ T cells. The Treg cells were subsequently identified by the abundance of the forkhead box protein P3 (Foxp3) transcriptional regulator. Foxp3+ cells develop in the thymus as natural Treg cells, or differentiate from naïve $T$ lymphocytes in the presence of TGF- $\beta$ as immune Treg cells. Natural Treg cells expressing the inducible co-stimulate use IL-10 to suppress DC functions, and TGF- $\beta$ to restrain T cells. Treg cells that do not express this inducible co-stimulate require TGF- $\beta$ only [34].

The reports are contradictory in that the blood of SS patients contains too many [35] or too few Treg cells [36]. The real setting could be that Foxp3+ lymphocytes circulating in the blood correlate inversely with those infiltrating the SGs [37]. The fact that there are fewer Treg cells in advanced than in mild SG infiltrates supports the view that DC-derived TGF- $\beta$ induces Foxp3 in naïve T cells and switches T-cell differentiation from the defective Treg cell pathway to a Th17 differentiation pathway in the presence of IL-6 [30,31].
Similarly, IL-18, which can be secreted by epithelial cells, has been detected in periductal mononuclear cells (MNCs), and correlated with infiltrating macrophages and increases in serum IL-18 [26]. This supplemental mediator would regulate the Th1 response and amplify IL-17 synthesis [27]. At the time of its identification, the pathological role of IL-18 in the SGs of SS patients was unclear. Since then, we have learned that IL-18 acts as a chemoattractant for $\mathrm{CD} 4+\mathrm{T}$ cells and a stimulator for antigen-presenting cells, required for the generation of Th17 cells (Figure 2). Furthermore, IL-18 promotes the synthesis of proinflammatory cytokines, enhances the secretion of chemokines and worsens tissue damage through cell-mediated cytotoxicity and release of matrix metalloproteinases [28]. Ultimately, a handful of macrophages and DCs can play an IL-18-mediated active role in the SGs and in MNC infiltration.

\section{The role of IL- 6 in Sjögren's syndrome Up-regulation of IL-6}

Not only does IL- 6 participate in the generation of Th17 cells but it also fosters their proliferation and is associated with multiple effects in patients with SS, whose SGs have been shown to contain IL-6. Given that it is also derived from Th17 cells [38], IL-6 can activate local B cells in an autocrine manner. The $80-\mathrm{kDa}$ glycoprotein (gp) receptor for IL-6 associates with a signal-transducing 130-kDa gp chain to shape a membrane-bound aggregate. The receptor for IL-6 also exists in a soluble form capable of binding to transmembrane gp130 and facilitating signal transduction through homodimerization of gp130 to the ligand-receptor complex [39]. Thus, IL-6 exerts seemingly opposite effects by lending strength to Th17 cells and exerting polyclonal activation of $\mathrm{B}$ cells.

\section{IL-6-related T- and B-cell biology}

In the presence of IL-6, Th17 cells orchestrate the development of GCs dominated by autoreactive lymphocytes [40], such as those that we have described in the SGs of SS patients [41]. Moreover, IL-6 contributes to the expression of recombination-activating genes (Rags). Even though some of the activities of IL- 6 proceed via its soluble form, the predominance of complexes of IL- 6 and the IL- 6 receptor is the therapeutic rationale for targeting the receptor rather than the cytokine. The soluble form may retain IL-6 and the complex bound to gp130 on the cell membrane and, thus, engage the receptor to the membrane again.

This pivotal cytokine seems to be responsible for abnormal B-cell antigen receptor (BCR)-mediated regulation of Rag genes in B cells in SS patients. Our own data [42] indicate that, along with BCR engagement, IL-6 signaling results in secondary Ig gene rearrangements, and thereby favors the generation of auto-antibodies. Of 


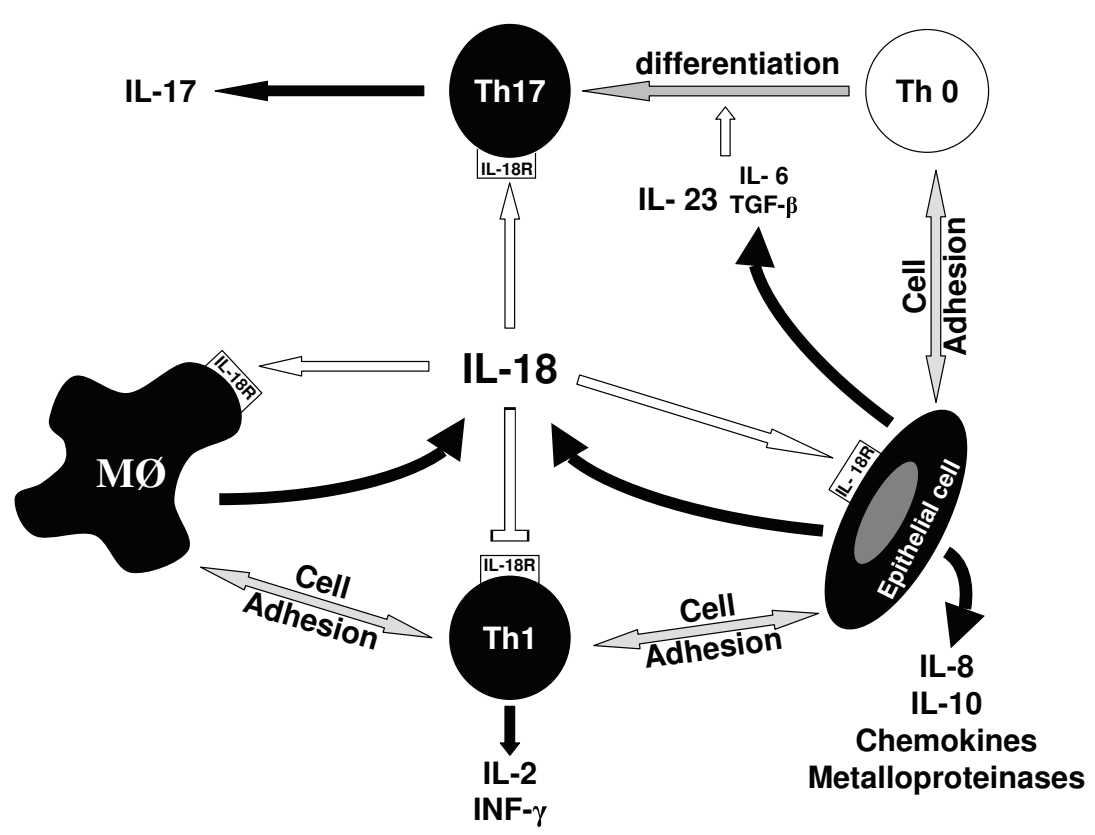

Figure 2. The network of T helper (Th) cells gathers together Th0, Th1, Th2 and Th17 lymphocytes. The production of IFN- $\gamma$, transforming growth factor (TGF)- $\beta$ and various interleukins is indicated. $M \varnothing$, macrophage.

further interest is the limiting effect of IL-6 on the generation of Treg lymphocytes, and the ultimate suppressive effect of the latter cells on B lymphocyte responses.

\section{Dysregulated production of IL- 6 by $B$ cells}

As described in patients with rheumatoid arthritis and systemic lupus erythematosus, their spontaneous activation can induce $\mathrm{B}$ lymphocytes to release copious amounts of IL- 6 in primary SS [43]. Furthermore, the IL-6 receptor is preferentially expressed on B cells in patients with active disease, and thereby preferentially stimulates the differentiation of autoreactive $B$ lymphocytes.

\section{B-cell cytokines}

\section{Polarized B lymphocytes}

$B$ cells possess the capacity to produce a range of cytokines. These may be grouped as proinflammatory cytokines, such as IL-1, IL-6, TNF- $\alpha$ and lymphotoxin (LT)- $\alpha$; as immunosuppressive cytokines, such as TGF- $\beta$ and IL-10; or as hematopoietic growth factors, such as IL-7 and granulocyte/macrophage-colony stimulating factor. The third family facilitates Th1 cell polarization and the production of TNF- $\alpha$ by DCs, and derives from macrophages and endothelial cells in the SGs of patients with SS [44].

In reality, the major breakthrough in determining the potential role of B cells in diseases occurred when two distinct cytokine-secreting subsets were identified through the culture of $\mathrm{B}$ cells with effector $\mathrm{T}$ cells associated with their cognate antigens [15]. B lymphocytes polarized in the presence of Th1 cells were designated $\mathrm{B}$ effector $(\mathrm{Be}) 1$ cells, based on their signature cytokines, IFN- $\gamma$ and IL-2, in the expected presence of Tbet. Conversely, Th2 cells induced naïve B lymphocyte polarization into $\mathrm{Be} 2$ cells, which produced IL-4 and IL-6, in the unexpected absence of GATA-3. However, IL-10, LT- $\beta$, TGF- $\beta$, and TNF- $\alpha$ were similarly expressed in $\mathrm{Be} 1$ and $\mathrm{Be} 2$ cells, yielding an ever-growing complexity of these B-cell subsets.

The kinetics of Be cell generation and the cytokine profile of $B$ cells raise the possibility that the Th1 phenotype is imprinted on Be1 cells through IL-2 and that expression of IFN- $\gamma$ by B cells is sustained through an autocrine loop between IFN- $\gamma$ and the IFN- $\gamma$ receptor. However, the differentiation of naïve $B$ lymphocytes into IL-4-producing $\mathrm{Be} 2$ cells is controlled by T-celldependent signals. Of important note, IL-4 is generated by GC B cells and is necessary for Th2 polarization [45].

\section{Interconnections between the B- and T-cell cytokine networks}

LTs are implicated in establishing and maintaining the organization of normal lymphoid tissues. Mice in which LT- $\alpha$ [46] and/or LT- $\beta$ [47] signaling is disrupted suffer from disturbances in splenic architecture. Intriguing also is the finding that DC networks, conspicuous components of B-cell follicles, are lacking in different LT knockout mice [48]. Gonzalez and colleagues [49] showed that 
B lymphocytes induce membrane LT- $\alpha$, and that the transfer of B cells (but not T cells) from membrane LT- $\alpha$ positive mice (but not membrane LT- $\alpha$-negative mice) governed the emergence of soluble LT- $\alpha$ in the SGs of IL-14 $\alpha$ transgenic mice, a model of primary SS [50]. Thus, signaling through LT- $\alpha$ was necessary to reduce aspects of SS in the SGs of non-obese diabetic mice [51].

Activated Th cells crosstalk with activated B cells to regulate their respective responses. Conversely, Be cells modulate T-cell polarization. The factors that affect T-cell differentiation toward Th1 cells induce naïve $B$ cells to produce IFN- $\gamma$ via activation of Stat-3, the phosphorylation of which is initiated by IL-12 [52]. A high level of expression of IL-12 has been found in the SGs of SS patients [53], and IL-12-induced SG dysfunction in IL-12 transgenic mice offers a new model for primary SS [54]. MNCs infiltrate their exocrine tissues, suggesting that IL-12 contributed to the circuit involving autoreactive $T$ and $B$ cells in SS. Interestingly, IL-10 produced by $B$ cells suppresses IL- 12 production by DCs, thus blocking Th1 cell responses.

Once B cells have been induced to produce IFN- $\gamma$, the presence of Th1 is no longer required to maintain polarized Be cells. This is because antigen-specific B lymphocytes take up antigen for presentation to $\mathrm{T}$ cells and, by doing so, create a self-sustaining circuit of $B$ and $T$ cells through which other naïve $\mathrm{T}$ cells may be recruited.

Aside from promoting Th1 cell polarization, Be1 cells amplify IFN- $\gamma$ production by $T$ cells via a TNF- $\alpha-$ mediated mechanism. Polarization of $B$ cells may take place at sites of inflammation, such as affected SGs [55]. Although patients with ectopic GCs have lower levels of Be2 cytokines than other SS patients, accumulating evidence supports the view that most of these B-cell clusters do not fulfill the requisites for ectopic GCs, but constitute aggregates of immature B cells [36]. However, the high affinity and class switch of auto-antibodies produced imply a local break of B-cell tolerance.

As suggested above, the proinflammatory IL-17, normally considered a T-cell-associated factor, has also been reported to be a central driver of GC-derived autoantibodies. This was demonstrated by blocking IL-17 signaling that disrupted the $\mathrm{CD}^{+}{ }^{+} \mathrm{T}$-cell and B-cell interactions required for the formation of GCs [40].

Additionally, memory B cells are markedly reduced in the circulation, possibly due to retention in inflamed SGs [56]. Their ensuing accumulation, along with shedding of surface CD27 [57], and altered recirculation of B-cell subsets from these sites may all participate in the disturbed B-cell homeostasis in primary SS [58]. Given that CD27+ memory B cells present with a higher transmigratory capacity to CXCL12, also termed stromal cell-derived factor-1 (SDF-1), and to CXCL13, also termed B-cell-attracting chemokine-1 (BCA-1), than
CD27- naïve B cells [59], glandular coexpression of these two chemokines $[6,7,60]$ directs memory B cells preferentially into inflamed SGs, where they reside [61].

\section{Regulatory circuits \\ The transcription factor Tbet in T and $B$ lymphocytes}

The finding of Tbet in B cells had, in fact, been preceded by its description in $\mathrm{T}$ cells. Not only does the binding of IFN- $\gamma$ to its receptor on the surface of naïve $\mathrm{T}$ cells activate and hence translocate Stat- 1 into the nucleus, but this interaction also promotes the expression of transcription factors involved in Th1 development. Thus, Tbet induces the transcription of the IFN- $\gamma$ gene, as well as the expression of receptors for IL-12. The net result is that $\mathrm{T}$ cells become responsive to IL-12, and translocate Stat-1 into the nucleus, where IFN- $\gamma$ expression is induced. In turn, IFN- $\gamma$ drives $\mathrm{T}$ cells along the Th1 pathway through a positive feedback loop.

Similarly, naïve B cells are equipped with receptors for IFN- $\gamma$, and can be induced to release Tbet-triggered IFN- $\gamma$ in the presence of IL-12. Then, B-cell-derived IFN$\gamma$ activates B cells in an autocrine manner, and amplifies Th1 responses through a paracrine pathway [55]. Consistent with this view is that Tbet-deficient murine B cells skew antibody isotypes toward IgG1 and IgE, which are isotypes favored by $\mathrm{Be} 2$ cells.

\section{GATA-3 and T-cell differentiation}

The absence of GATA-3 in Be cells raises the question of whether it can be replaced by other transcription factors. By counteracting Tbet in T cells, GATA-3 regulates Th polarization directly and Be cell generation indirectly [62]. This transcription factor diverts T-cell differentiation towards Th2 cells by silencing Th1-cell-specific transcription factor, and thereby enabling Th2 cells to proliferate. Co-culture of naïve B cells with Th2 cells inhibits Tbet, reduces IFN- $\gamma$ production and reverses the up-regulation of receptors for IL-12. Conversely, upregulation of IL-4 in Be2 cells depends on both $\mathrm{T}$ cells and IL-4. This is why B lymphocytes deficient in the receptor for IL-4 do not transcribe IL-4, and why B cells primed by IL-4-deficient Th2 cells substitute IFN- $\gamma$ for IL-4. Put simply, Tbet (in T cells, but also in B cells) and GATA-3 (in T cells, but also in B cells) suppress cytokines synthesized by the opposing Th cell subpopulation.

\section{B-cell-modulating factors in Sjögren's syndrome A new generation of ligands and receptors}

Two cytokines and their receptors have been demonstrated to be key in B-cell homeostasis: BAFF, which rescues $B$ cells from apoptosis, and APRIL, which participates in B-cell activation [63]. Like most members of the TNF family, BAFF is a transmembrane type I protein that can be cleaved by a furin convertase to produce a $17-\mathrm{kDa}$ 
soluble form. The biologically active form of BAFF is trimeric, but 20 trimers can also associate to form a virus-like 60-mer structure. APRIL and BAFF, referred to as growth factors rather than cytokines by some investigators, have two receptors in common: the B-cell maturation antigen (BCMA) and the transmembrane activator calcium modulator and cyclophilin ligand interactor (TACI). In addition, BAFF binds specifically to BAFF receptor 3 (BR3), whereas heparin sulfate proteoglycans are specific receptors for APRIL. BAFF receptors are mainly expressed on B cells, but, for each receptor, cell membrane density varies from transitional type-1 (T1) $\mathrm{B}$ lymphocytes to plasma cells. In humans, BR3 is present in BT1 cells to memory B cells, but not in plasma cells.

BAFF is critical for B cells to survive in the periphery. It is also involved in B-cell selection by dictating set points for mature primary B-cell numbers and adjusting thresholds for specificity-based selection during downstream differentiation. This cytokine has, therefore, aroused much interest because of its association with maintaining and breaching tolerance (Figure 3). Normally, few immature B cells successfully pass to the T2 stage. Irrespective of the level of receptor expression, BAFF is the dominant agent in the resistance of BT2 cells to apoptosis. In its absence, B-cell maturation is arrested at the T1 cell stage, while BAFF transgenic mice manifest T2 cell hyperplasia in their exocrine glands, which is reminiscent of the B-cell aggregates in the SGs of SS patients. The mice, then, develop systemic lupus erythematosus and SS-like disease [64]. The explanation is that excess BAFF protects self-reactive B cells from deletion and allows them to move to forbidden follicle or marginal zone (MZ) niches [65].

In the SGs of BAFF transgenic mice, the expanded MZ B-cell compartment comprises self-reactive B cells $[40,64,66]$, in contrast to a splenic architecture in $L T \alpha / \beta-$ deficient mice, which lack a structured MZ, preventing MZ B-cell development [67]. Noticeable in this regard is that the progeny of BAFF transgenic mice crossed with LT knockout mice lack MZ B cells and do not develop sialadenitis [68]. These results came as no surprise, while more intriguingly, Treg cell expansion through B-celldependent mechanisms [69] leads to profoundly compromised T-cell responses [70]. Based on these characteristics, BAFF might be regarded as a cytokine rather than a growth factor for $B$ cells.

BAFF is produced by all sorts of macrophages and DCs, and from epithelial cells and activated T lymphocytes. Its mRNA has also been detected in myeloid cells, bone marrow-derived stromal cells, astrocytes, and fibroblastlike synoviocytes in response to proinflammatory cytokines. At the protein level, BAFF exists as a membraneassociated molecule, or a cell-free protein, whereas APRIL occurs only in a soluble form.

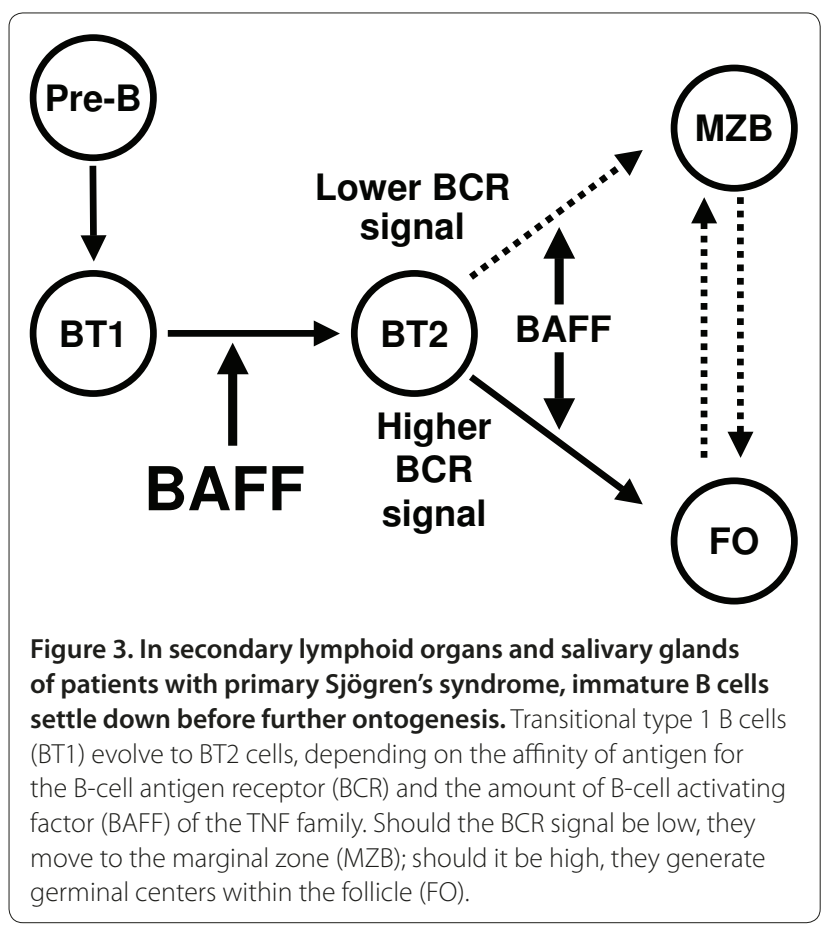

BAFF overexpression and Sjögren's syndrome

Serum levels of BAFF are increased in association with auto-antibodies in patients with primary SS. Moreover, high levels of BAFF in the serum and saliva of these individuals [71] are associated with anti-sicca syndrome A and anti-sicca syndrome B antibodies and/or rheumatoid factor and/or anti-double-stranded DNA antibody, in some [72,73], but not all $[74,75]$, patients with SS, rheumatoid arthritis or systemic lupus erythematosus. There exists, however, the issue of why serum levels of BAFF remain within, or even below, normal levels in a proportion of SS patients [76]. In addition, estimates of BAFF fluctuate with changes in inflammatory activity. Convinced that such fluctuations could be due to flaws or variations in enzyme-linked immunosorbent assays, we developed an in-house assay [77] and detected elevated levels of BAFF in the sera of most SS patients.

BAFF, therefore, is a genuinely promising target for therapy, along with IL-6. Such a combination seems to be in some conflict, since BAFF promotes B-cell responses whilst IL-6 promotes the Th17 axis. However, IL-6 is also a prevailing factor in polyclonal activation of B cells, and by rescuing $B$ cells from apoptosis, it promotes their production of IL-6. It is unclear at this stage which of the three cytokines, IL-6, BAFF or IL-17, should be considered the driving force since IL-6-induced B-cell activation also promotes BAFF production [32,38,42,55], and since local BAFF gene silencing suppresses Th17 cell generation and ameliorates autoimmune arthritis [78]. These data reveal that IL-17 is an effector cytokine for BAFF-mediated proinflammatory effects. 
Another mouse model, the Act1-knockout mouse, provided information on the signaling pathways induced by BAFF in the development of SS. Act1 is a negative regulator in CD40- and BAFF-mediated B-cell survival [79]. It is relevant that co-stimulation with BAFF rescues Act1-deficient T1 and T2 B lymphocytes from BCRinduced apoptosis. Consequently, Act1 knockout mice develop autoimmune manifestations similar to SS. Thus, Act1 is negative for B-cell-mediated humoral responses [80], but instead positive for the IL-17 signaling pathway [81].

There have been reports that the aberrant production of these cytokines could be due to excess IFN- $\alpha$ produced by plasmacytoid DCs [82]. A credible candidate for the induction of IFN- $\alpha$ secretion by plasmacytoid DCs is viral infection. Alternatively, IFN- $\alpha$ production in SS may be induced by immune complexes containing nucleic acids. The role of this cytokine in SS was recently reviewed by Mavragani and Crow [83]. They highlighted the noted increase in circulating type-1 IFN and an IFN signature in peripheral blood MNCs and minor SGs from SS patients [84]. Altered levels of production of this cytokine may be dependent on genetic and/or epigenetic mechanisms [85], and its blockade therefore is a logical therapeutic target for the treatment of SS.

More importantly, there is good evidence that local production of BAFF contributes to deleterious effects of activated B cells by raising their expression of CD19 molecules [4], and ensuring survival of B-cell aggregates, and auto-antibody isotype switching outside and inside GCs [41]. This process is sustained by the aberrant expression of BAFF by B lymphocytes infiltrating the SGs $[86,87]$.

\section{Aberrant production of BAFF by B cells in SS patients}

Indeed, due to the dependency of newly formed $B$ cells on BAFF, it is tempting to believe that this cytokine needs to be produced in tissue nearby the cell aggregates. We have demonstrated aberrant expression of BAFF not only in epithelial cells and activated T lymphocytes, but also by single cells isolated from the SGs and by B lymphocytes infiltrating the SGs of patients with SS [87]. Such might be the reason why rituximab-induced B-cell depletion reduces the Th17 response [88] in rheumatoid arthritis synovium as well as that of normal Th17 cells in the absence of B cells in culture. This finding is also consistent with in vitro and in vivo evidence [89] that activation of B cells induces BAFF and APRIL expression in B cells from normal and autoimmunity-prone mice. Production of BAFF by $\mathrm{B}$ lymphocytes is unusual, but malignant $B$ cells produce BAFF [90], which promotes their survival in an autocrine manner. This aberrancy is caused by amplification of the BAFF gene in B cells.

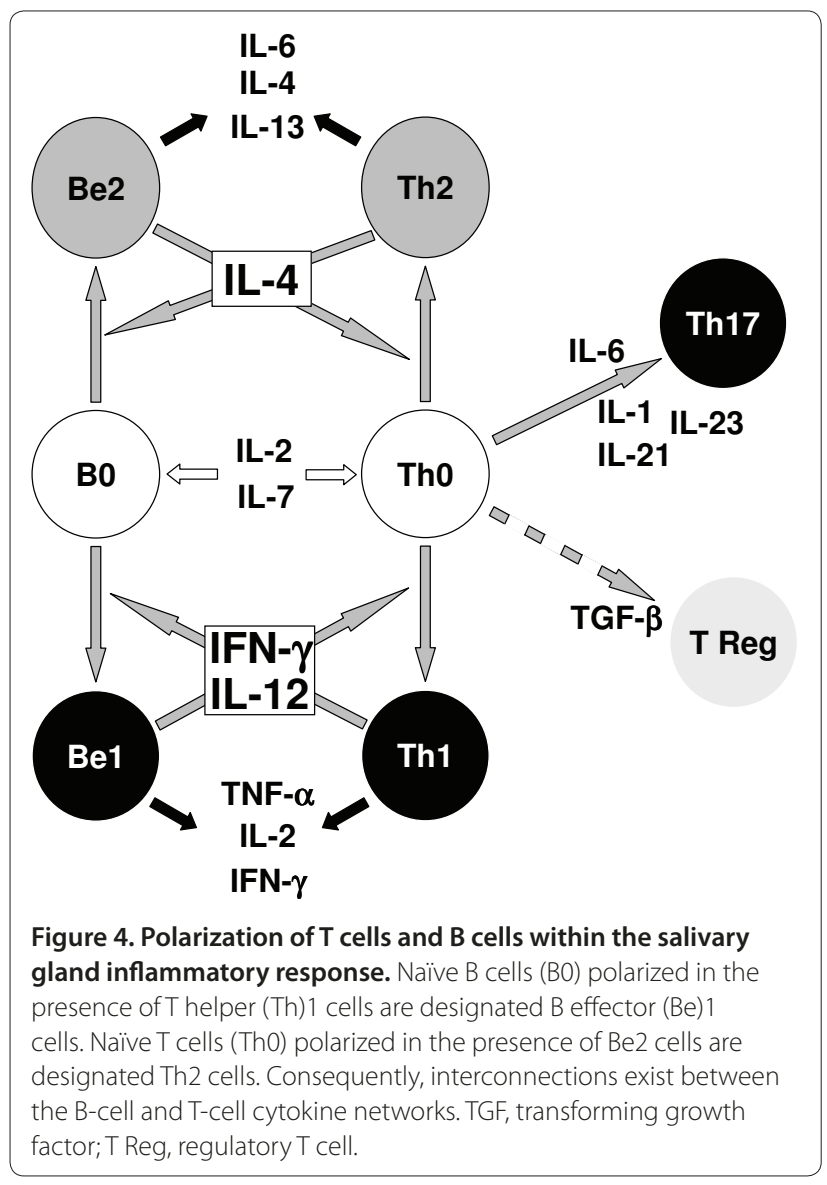

\section{Conclusion}

There is little doubt that exploring the role of cytokines in SS is a highly promising field of investigation. How the cells and cytokines interact to promote the development of SS is summarized in Figure 4. In general, B-cell depletion has provided clinical benefits [91-95]. Some failures might be ascribed [95] to imbalances in Th cell subsets or the depletion of Breg cells. Such striking conceptual advances offer novel perspectives in the treatment of primary SS. Clearly, IL-6, IL-17 and BAFF are major agents in the pathogenesis of SS and, therefore, cytokine targeting would have great therapeutic potential. Nevertheless, B-cell-directed therapies notwithstanding [94], much uncertainty remains as to the best therapeutic

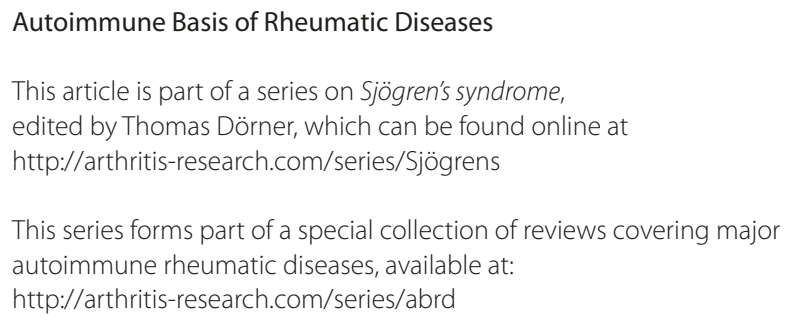

This series forms part of a special collection of reviews covering major autoimmune rheumatic diseases, available at:

http://arthritis-research.com/series/abrd 
strategy for the treatment of SS. Further development of biotherapies is beyond the scope of this review. However, we can reasonably expect progress in the near future based on the aforementioned new insights into disturbances of the cytokine networks in SS.

\section{Abbreviations}

APRIL, a proliferation-inducing ligand; BAFF, B-cell-activating factor; BCR, B cell antigen receptor; Be, B effector; Breg, regulatory B; DC, dendritic cell; GC, germinal center; gp, glycoprotein; IFN, interferon; Ig, immunoglobulin; IL, interleukin; LT, lymphotoxin; MNC, mononuclear cell; MZ, marginal zone; Rag, recombination-activating gene; SG, salivary gland; SS, Sjögren's syndrome; Stat, signal transducer and activator of transcription; TGF, transforming growth factor; Th, Thelper; TNF, tumor-necrosis factor; Treg, regulatory T.

\section{Competing interests}

The authors declare that they have no competing interests.

\section{Acknowledgments}

We acknowledge Professor Rizgar A Mageed (William Harvey Institute, and Queen Mary School of Medicine, London, United Kingdom) for critical reading of our manuscript. We thanks Geneviève Michel and Simone Forest for their help with the typing of the manuscript.

\section{Author details}

"Research Unit "Immunology and Pathology" at the European University of Brittany, Brest, 29609, France. ${ }^{2}$ Laboratory of Immunology, Brest University Medical School, Brest, 29609, France.

Published: 6 July 2011

\section{References}

1. Moutsopoulos HM: Sjögren's syndrome: autoimmune epithelitis. Clin Immunol Immunopathol 1994, 72:162-165.

2. Gershwin ME: The mosaic of autoimmunity. Autoimmun Rev 2008, 7:161-163.

3. Christodoulou MI, Kapsogeorgou EK, Moutsopoulos HM: Characteristics of the minor salivary gland infiltrates in Sjögren's syndrome. J Autoimmun 2010, 34:400-407.

4. d'Arbonneau F, Pers JO, Devauchelle V, Pennec Y, Saraux A, Youinou P: BAFF-induced changes in BCR-containing lipid rafts in Sjögren's syndrome. Arthritis Rheum 2006, 54:115-126.

5. Stott DI, Hiepe F, Hummel M, Steinhauser G, Berek C: Antigen-driven clonal proliferation of $B$ cells within the target tissue of an autoimmune disease. The salivary glands of patients with Sjögren's syndrome. J Clin Invest 1998, 102:938-946.

6. Salomonsson S, Jonsson MV, Skarstein K, Brokstad KA, Hjelmström P, WahrenHerlenius M, Jonsson R: Cellular basis of ectopic germinal center formation and autoantibody production in the target organ of patients with Sjögren's syndrome. Arthritis Rheum 2003, 48:3187-3201.

7. Barone F, Bombardieri M, Manzo A, Blades MC, Morgan PR, Challacombe SJ, Valesini G, Pitzalis C: Association of CXCL13 and CCL21 expression with the progressive organization of lymphoid-like structures in Sjögren's syndrome. Arthritis Rheum 2005, 52:1773-1784.

8. Hansen A, Lipsky PE, Dőrner T: Immunopathogenesis of primary Sjögren's syndrome: implications for disease management and therapy. Curr Opin Rheumatol 2005, 17:558-565.

9. Gor DO, Rose NR, Greenspan NS: Th1-Th2: a procrustean paradigm. Nat Immunol 2003, 4:503-505.

10. Mosmann TR, Coffman RL: Th1 and Th2 cells: different patterns of lymphokine secretion lead to different functional properties. Annu Rev Immunol 1989, 7:145-173.

11. Miossec P, Korn T, Kuchroo VK: Interleukin-17 and type 17 helper T cells. NEngl J Med 2009, 361:888-898.

12. Sakaguchi S, Yamaguchi T, Nomura T, Ono M: Regulatory T cells and immune tolerance. Cell 2008, 133:775-787.

13. Saraux A: The point on the ongoing B-cell depleting trials currently in progress over the world in primary Sjögren's syndrome. Autoimmun Rev 2010, 9:609-614

14. Youinou P, Devauchelle V, Pers JO: Significance of B cells and B cell clonality in Sjögren's syndrome. Arthritis Rheum 2010, 62:2605-2610.

15. Harris DP, Haynes L, Sayles PC, Duso DK, Eaton SM, Lepak NM, Johnson LL, Swain SL, Lund FE: Reciprocal regulation of polarized cytokine production by effector B and T cells. Nat Immunol 2000, 1:475-482.

16. Jamin C, Morva A, Lemoine S, Daridon C, Revol de Mendoza A, Youinou P: Regulatory B lymphocytes in humans: a potential role in autoimmunity. Arthritis Rheum 2008, 58:1900-1906.

17. Mackay F, Silveira PA, Brink R: B cells and the BAFF/APRIL axis: fast-forward on autoimmunity and signaling. Curr Opin Immunol 2007, 19:327-336.

18. Szodoray P, Alex P, Brun JG, Centola M, Jonsson R: Circulating cytokines in primary Sjögren's syndrome determined by a multiplex cytokine array system. Scand J Immunol 2004, 59:592-599.

19. Crane IJ, Forrester JV: Th1 and Th2 lymphocytes in autoimmune disease. Crit Rev Immunol 2005, 25:75-102.

20. Hooks JJ, Moutsopoulos HM, Geis SA, Stahl NI, Decker JL, Notkins AL: Immune interferon in the circulation of patients with autoimmune disease. N Engl J Med 1979, 301:5-8.

21. Hagiwara E, Pando J, Ishigatsubo Y, Klinman DM: Altered frequency of type-1 cytokine secreting cells in the peripheral blood of patients with primary Sjögren's syndrome. J Rheumatol 1998, 25:89-93.

22. Boumba D, Skopouli FN, Moutsopoulos HM: Cytokine mRNA expression in the labial salivary gland tissues from patients with primary Sjögren's syndrome. Br J Rheumatol 1995, 34:326-333.

23. Wakamatsu E, Matsumoto I, Yasukochi T, Naito Y, Goto D, Mamura M, Ito S, Tsutsumi A, Sumida T: Overexpression of Stat-1a in the labial salivary glands of patients with Sjögren's syndrome. Arthritis Rheum 2006, 54:3476-3484.

24. van Woerkom JM, Kruize AA, Wenting-van Wijk MJ, Knol E, Bihari IC, Jacobs JW, Bijlsma JW, Lafeber FP, van Roon JA: Salivary gland and peripheral blood Thelper 1 and 2 cell activity in Sjögren's syndrome compared with nonSjögren's sicca syndrome. Ann Rheum Dis 2005, 64:1474-1479.

25. Mitsias DI, Tzioufas AG, Veiopoulou C, Zintzaras E, Tassios IK, Kogopoulou O, Moutsopoulos HM, Thyphronitis G: The Th1/Th2 cytokine balance changes with the progress of the immunopathological lesion of Sjögren's syndrome. Clin Exp Immunol 2002, 128:562-568.

26. Bombardieri M, Barone F, Pittoni V, Alessandri C, Conigliaro P, Blades MC, Prior $R$, McInnes IB, Valesini G, Pitzalis C: Increased circulating levels and salivary gland expression of IL-18 in patients with Sjögren's syndrome: relationship with autoantibody production and lymphoid organization of the periductal inflammatory infiltrate. Arthritis Res Ther 2004, 6:R447-456.

27. Sakai A, Sugawara Y, Kuroishi T, Sasano T, Sugawara S: Identification of IL-18 and Th17 cells in salivary glands of Sjögren's syndrome, and amplification of IL-17-mediated secretion of inflammatory cytokines from salivary gland cells by IL-18. J Immuno/ 2008, 181:2898-2906.

28. McInnes IB, Gracie JA, Leung BP, Wei XQ, Liew FY: Interleukin 18: a pleiotropic participant in chronic inflammation. Immunol Today 2000, 21:312-315.

29. Dardalhon V, Korn T, Kuchroo VK, Anderson AC: Role of Th1 and Th17 cells in organ-specific autoimmunity. J Autoimmun 2008, 31:252-256.

30. Romagnani S: Human Th17 cells. Arthritis Res Ther 2008, 10:2006.

31. Nguyen $\mathrm{CQ}, \mathrm{Hu}$ MH, LiY, Stewart C, Peck AB: Salivary gland tissue expression of IL-23 and IL-17 in Sjögren's syndrome: findings in humans and mice. Arthritis Rheum 2008, 58:734-743.

32. Mitsdoerffer M, Lee Y, Jäger A, Kim HJ, Korn T, Kolls JK, Cantor H, Bettelli E, Kuchroo VK: Proinflammatory T helper type 17 cells are effective B-cell helpers. Proc Natl Acad Sci U S A 2010, 107:14292-14297.

33. Katsifis GE, Rekka S, Moutsopoulos NM, Pillemer S, Wahl SM: Systemic and local IL-17 and linked cytokines associated with Sjögren's syndrome immunopathogenesis. Am J Pathol 2009, 175:1167-1177.

34. Ito T, Hanabuchi S, Wang YH, Park WR, Arima K, Bover L, Qin FX, Gilliet M, Liu $Y$ J: Two functional subsets of Foxp3+ regulatory $T$ cells in human thymus and periphery. Immunity 2008, 28:870-880

35. Gottenberg JE, Lavie F, Abbed K, Gasnault J, Le Nevot E, Delfraissy JF, Taoufik Y, Mariette $X: C D 4+C D 25$ high regulatory $T$ cells are not impaired in patients with primary Sjögren's syndrome. J Autoimmun 2005, 24:235-242.

36. Liu MF, Lin LH, Weng CT, Weng MY: Decreased CD4+CD25+bright T cells in peripheral blood of patients with primary Sjögren's syndrome. Lupus 2008 17:34-39.

37. Christodoulou MI, Kapsogeorgou EK, Moutsopoulos NM, Moutsopoulos HM: Foxp3+ T-regulatory cells in Sjögren's syndrome: correlation with the grade of the autoimmune lesion and certain adverse prognostic factors. 
Am J Pathol 2008, 173:1389-1396

38. Youinou P, Jamin C: The weight of IL-6 in B cell-related autoimmune disorders. J Autoimmun 2009, 32:206-210.

39. Nishimoto N, Kishimoto T: Interleukin 6: from bench to bedside. Nat Clin Pract Rheumatol 2006, 2:619-626.

40. Hsu HC, Yang P, Wang J, Wu Q, Myers R, Chen J, Yi J, Guentert T, Tousson A, Stanus AL, Le TV, Lorenz RG, Xu H, Kolls JK, Carter RH, Chaplin DD, Williams RW, Mountz JD: IL-17-producing Thelper cells and IL-17 orchestrate autoreactive germinal center development in autoimmune BXD2 mice. Nat Immunol 2008, 9:166-175.

41. Le Pottier L, Devauchelle V, Fautrel A, Daridon C, Saraux A, Youinou P, Pers JO: Ectopic germinal centers are rare in Sjögren's syndrome salivary glands and do not exclude autoreactive B cells. J Immunol 2009, 182:3540-3547.

42. Hillion S, Dueymes M, Youinou P, Jamin C: IL-6 contributes to the expression of Rags in human mature B cells. J Immunol 2007, 179:6790-6798.

43. Kitani A, Hara M, Hirose T, Harigai M, Suzuki K, Kawakami M, Kawaguchi Y, Hidaka T, Kawagoe M, Nakamura H: Autostimulatory effects of IL-6 on excessive B cell differentiation in patients with SLE: analysis of IL-6 production and IL-6R expression. Clin Exp Immunol 1992, 88:75-83.

44. Bikker A, van Woerkom JM, Kruize AA, Wenting-van Wijk M, de Jager W, Bijlsma JW, Lafeber FP, van Roon JA: Increased expression of IL-7 in labial salivary glands of patients with primary Sjögren's syndrome correlates with increased inflammation. Arthritis Rheum 2010, 62:969-977.

45. Harris DP, Goodrich S, Mohrs K. Mohrs M, Lund FE: The development of IL-4-producing B cells is controlled by IL-4, IL-4R a, and Th2 cells. I Immuno/ 2005, 175:7103-7107.

46. Ettinger R, Browning JL, Michie SA, van Ewijk W, McDevitt HO: Disrupted splenic architecture, but normal lymph node development in mice expressing a soluble LT $\beta$ receptor-lgG1 fusion protein. Proc Natl Acad SCi USA 1996, 93:13102-13107.

47. Rennert PD, Browning JL, Mebius R, Mackay F, Hochman PS: Surface LTa/ $\beta$ complex is required for the development of peripheral lymphoid organs. J Exp Med 1996, 184:1999-2006.

48. Mackay F, Majeau GR, Lawton P, Hochman PS, Browning JL: Lymphotoxin but not TNF functions to maintain splenic architecture and humoral responsiveness in adult mice. Eur J Immunol 1997, 27:2033-2042.

49. Gonzalez M, Mackay F, Browning JL, Kosco-Vilbois MH, Noelle RJ: The sequential role of $L T$ and $B$ cells in the development of splenic follicles. J Exp Med 1998, 187:997-1007.

50. Gatumu MK, Skarstein K, Papandile A, Browning JL, Fava RA, Bolstad Al: Blockade of LT $\beta$ receptor signaling reduces aspects of Sjögren's syndrome in salivary glands of NOD mice. Arthritis Res Ther 2009, 11:R24.

51. Shen L, Suresh L, Wu J, Xuan J, Li H, Zhang C, Pankewycz O, Ambrus JL Jr: A role for lymphotoxin in primary Sjögren's disease. J Immunol 2010, 185:6355-6363

52. Durali D, de Goër de Herve MG, Giron-Michel J, Azzarone B, Delfraissy JF, Taoufik Y: In human B cells, IL-12 triggers a cascade of molecular events similar to Th1 commitment. Blood 2003, 102:4084-4089.

53. Manoussakis MN, Boiu S, Korkolopoulou P, Kapsogeorgou EK, Kavantzas N, Ziakas P, Patsouris E, Moutsopoulos HM: Rates of infiltration by macrophages and dendritic cells and expression of IL-18 and IL-12 in the chronic inflammatory lesions of Sjögren's syndrome: correlation with certain features of immune hyperactivity and factors associated with high risk of lymphoma development. Arthritis Rheum 2007, 56:3977-3988

54. Vosters JL, Landek-Salgado MA, Yin H, Swaim WD, Kimura H, Tak PP, Caturegli P, Chiorini JA: IL-12 induces salivary gland dysfunction in transgenic mice, providing a new model of Sjögren's syndrome. Arthritis Rheum 2009, 60:3633-3641

55. Daridon C, Guerrier T, Devauchelle V, Saraux A, Pers JO, Youinou P: Polarization of B effector cells in Sjögren's syndrome. Autoimmun Rev 2007, 6:427-431

56. Hansen A, Odendahl M, Reiter K, Jacobi AM, Feist E, Scholze J, Burmester GR, Lipsky PE, Dörner T: Diminished peripheral blood memory B cells and accumulation of memory $B$ cells in the salivary glands of patients with Sjögren's syndrome. Arthritis Rheum 2002, 46:2160-2171.

57. Hansen A, Gosemann M, Pruss A, Reiter K, Ruzickova S, Lipsky PE, Dőrner T: Abnormalities in peripheral $B$ cell memory of patients with primary Sjögren's syndrome. Arthritis Rheum 2004, 50:1897-1908.

58. Hansen A, Daridon C, Dőrner T: What do we know about memory B cells in primary Sjögren's syndrome? Autoimmun Rev 2010, 9:600-603.

59. Hansen A, Reiter K, Ziprian T, Jacobi A, Hoffmann A, Gosemann M, Scholze J,
Lipsky PE, Dőrner T: Dysregulation of chemokine receptor expression and function by B cells of patients with primary Sjögren's syndrome. Arthritis Rheum 2005, 52:2109-2119

60. Xanthou G, Polihronis M, Tzioufas AG, Paikos S, Sideras P, Moutsopoulos HM: "Lymphoid" chemokine mRNA expression by epithelial cells in the chronic inflammatory lesion of the salivary glands of Sjögren's syndrome patients: possible participation in lymphoid structure formation. Arthritis Rheum 2001, 44:408-418

61. Salvatore P, Pagliarulo C, Colicchio R, Napoli C: CXCR4-CXCL12-dependent inflammatory network and endothelial progenitors. Curr Med Chem 2010, 17:3019-3029

62. Zheng W, Flavell RA: The transcription factor GATA-3 is necessary and sufficient for Th2 cytokine gene expression in CD4 T cells. Cell 1997, 89:587-596.

63. Mackay F, Schneider P, Rennert P, Browning J: BAFF and APRIL: a tutorial on B-cell survival. Annu Rev Immunol 2003, 21:231-264.

64. Groom J, Kalled SL, Cutler AH, Olson C, Woodcock SA, Schneider P, Tschopp J, Cachero TG, Batten M, Wheway J, Mauri D, Cavill D, Gordon TP, Mackay CR, Mackay F: Association of BAFF/BLyS overexpression and altered B-cell differentiation with Sjögren's syndrome. J Clin Invest 2002, 109:59-68.

65. Thien M, Phan TG, Gardam S, Amesbury M, Basten A, Mackay F, Brink R: Excess BAFF rescues self-reactive $B$ cells from peripheral deletion and allows them to enter forbidden follicular and marginal zone niches. Immunity 2004, 20:785-798

66. Tengnér P, Halse AK, Haga HJ, Jonsson R, Wahren-Herlenius M: Detection of anti-Ro/SSA and anti-La/SSB autoantibody-producing cells in salivary glands from patients with Sjögren's syndrome. Arthritis Rheum 1998, 41:2238-2248

67. Ngo VN, Korner H, Gunn MD, Schmidt KN, Riminton DS, Cooper MD, Browning JL, Sedgwick JD, Cyster JG: LTa/ $\beta$ and TNF are required for stromal cell expression of homing chemokines in B and $\mathrm{T}$ cell areas of the spleen. J Exp Med 1999, 189:403-412.

68. Fletcher CA, Sutherland AP, Groom JR, Batten ML, Ng LG, Gommerman J, Mackay F: Development of nephritis but not sialadenitis in autoimmuneprone BAFF transgenic mice lacking marginal zone B cells. Eur J Immunol 2006, 36:2504-2514.

69. Lemoine S, Morva A, Youinou P, Jamin C: Human T cells induce their own regulation through activation of B cells. J Autoimmun 2011, 36:228-238.

70. Walters S, Webster KE, Sutherland A, Gardam S, Groom J, Liuwantara D, Mariño E, Thaxton J, Weinberg A, Mackay F, Brink R, Sprent J, Grey ST: Increased CD4+Foxp3+T cells in BAFF-transgenic mice suppress T cell effector responses. J Immunol 2009, 182:793-801.

71. Pers JO, d'Arbonneau F, Devauchelle-Pensec V, Saraux A, Pennec YL, Youinou $P$ : Is periodontal disease mediated by salivary BAFF in Sjögren's syndrome? Arthritis Rheum 2005, 52:2411-2414

72. Mariette X, Roux S, Zhang J, Bengoufa D, Lavie F, Zhou T, Kimberly R: The level of BLyS (BAFF) correlates with the titre of autoantibodies in human Sjögren's syndrome. Ann Rheum Dis 2003, 62:168-171.

73. Bosello S, Youinou P, Daridon C, Tolusso B, Bendaoud B, Pietrapertosa D, Morelli A, Ferraccioli G: Concentrations of BAFF correlate with autoantibody levels, clinical disease activity, and response to treatment in early rheumatoid arthritis. J Rheumatol 2008, 35:1256-1264.

74. Becker-Merok A, Nikolaisen C, Nossent HC: B-lymphocyte activating factor in systemic lupus erythematosus and rheumatoid arthritis in relation to autoantibody levels, disease measures and time. Lupus 2006, 15:570-576.

75. Toubi E, Kessel A, Rosner I, Rozenbaum M, Paran D, Shoenfeld Y: The reduction of serum B-lymphocyte activating factor levels following quinacrine add-on therapy in systemic lupus erythematosus. Scand $\rfloor$ Immunol 2006, 63:299-303.

76. Youinou P, Pers JO: The late news on baff in autoimmune diseases. Autoimmun Rev 2010, 9:804-806

77. Le Pottier L, Bendaoud B, Renaudineau Y, Youinou P, Pers JO, Daridon C New ELISA for B cell-activating factor. Clin Chem 2009, 55:1843-1851.

78. Lai Kwan Lam Q, King Hung Ko O, Zheng BJ, Lu L: Local BAFF gene silencing suppresses Th17-cell generation and ameliorates autoimmune arthritis. Proc Natl Acad Sci U S A 2008, 105:14993-14998.

79. LiX: Act1 modulates autoimmunity through its dual functions in CD40L/ BAFF and IL-17 signaling. Cytokine 2008, 41:105-113.

80. Qian Y, Qin J, Cui G, Naramura M, Snow EC, Ware CF, Fairchild RL, Omori SA, Rickert RC, Scott M, Kotzin BL, Li X: Act1, a negative regulator in CD40- and BAFF-mediated B cell survival. Immunity 2004, 21:575-587. 
81. Qian Y, Liu C, Hartupee J, Altuntas CZ, Gulen MF, Jane-Wit D, Xiao J, Lu Y, Giltiay N, Liu J, Kordula T, Zhang QW, Vallance B, Swaidani S, Aronica M, Tuohy VK, Hamilton T, Li X: The adaptor Act1 is required for interleukin 17-dependent signaling associated with autoimmune and inflammatory disease. Nat Immunol 2007, 8:247-256.

82. Lövgren T, Eloranta ML, Båve U, Alm GV, Rönnblom L: Induction of IFN-a production in plasmacytoid dendritic cells by immune complexes containing nucleic acid released by necrotic or late apoptotic cells and lupus IgG. Arthritis Rheum 2004, 50:1861-1872.

83. Mavragani CP, Crow MK: Activation of the type-I IFN pathway in primary Sjögren's syndrome. J Autoimmun 2010, 35:225-231.

84. Gottenberg JE, Cagnard N, Lucchesi C, Letourneur F, Mistou S, Lazure T, Jacques S, Ba N, Ittah M, Lepajolec C, Labetoulle M, Ardizzone M, Sibilia J, Fournier C, Chiocchia G, Mariette X: Activation of IFN pathways and plasmacytoid dendritic cell recruitment in target organs of primary Sjögren's syndrome. Proc Natl Acad Sci U S A 2006, 103:2770-2775.

85. Renaudineau Y, Youinou P: Epigenetics and autoimmunity, with special emphasis on methylation. Keio J Med 2011, 60:10-16.

86. Daridon C, Pers JO, Devauchelle V, Martins-Carvalho C, Hutin P, Pennec YL, Saraux A, Youinou P: Identification of transitional type II B cells in thesalivary glands of patients with Sjögren's syndrome. Arthritis Rheum 2006, 54:2280-2288.

87. Daridon C, Devauchelle V, Hutin P, Le Berre R, Martins-Carvalho C, Bendaoud B, Dueymes M, Saraux A, Youinou P, Pers JO: Aberrant expression of BAFF by $B$ lymphocytes infiltrating the salivary glands of patients with primary Sjögren's syndrome. Arthritis Rheum 2007, 56:1134-1144.

88. van de Veerdonk FL, Lauwerys B, Marijnissen RJ, Timmermans K, Di Padova F, Koenders MI, Gutierrez-Roelens I, Durez P, Netea MG, van der Meer JW, van den Berg WB, Joosten $L A$ : The anti-CD20 antibody rituximab reduces the Thelper 17 response. Arthritis Rheum 2011, 63:1507-1516.
89. Varin MM, Le Pottier L, Youinou P, Saulep D, Mackay F, Pers JO: B-cell tolerance breakdown in Sjögren's syndrome: focus on BAFF. Autoimmun Rev 2010, 9:604-608.

90. Kern C, Cornuel JF, Billard C, Tang R, Rouillard D, Stenou V, Defrance T, Ajchenbaum-Cymbalista F, Simonin PY, Feldblum S, Kolb JP: Involvement of BAFF and APRIL in the resistance to apoptosis of B-CLL through an autocrine pathway. Blood 2004, 103:679-688.

91. Dőrner T, Radbruch A, Burmester GR: B-cell-directed therapies for autoimmune disease. Nat Rev Rheumatol 2009, 5:433-441.

92. Pijpe J, van Imhoff GW, Spijkervet FK, Roodenburg JL, Wolbink GJ, Mansour K, Vissink A, Kallenberg CG, Bootsma H: Rituximab treatment in patients with Sjögren's syndrome: an open-label phase II study. Arthritis Rheum 2005, 52:2740-2750.

93. Devauchelle-Pensec V, Pennec Y, Morvan J, Pers JO, Daridon C, Jousse-Joulin S, Roudaut A, Jamin C, Renaudineau Y, Quentin-Roué I, Cochener B, Youinou $P$, Saraux A: Improvement of Sjögren's syndrome after two infusions of rituximab (anti-CD20). Arthritis Rheum 2007, 57:310-317.

94. Dass S, Bowman SJ, Vital EM, Ikeda K, Pease CT, Hamburger J, Richards A, Rauz S, Emery P: Reduction of fatigue in Sjögren syndrome with rituximab: results of a randomised, double-blind, placebo-controlled pilot study. Ann Rheum Dis 2008, 67:1541-1544.

95. Dőrner T, Radbruch A, Burmester GR: B-cell-directed therapies for autoimmune disease. Nat Rev Rheumatol 2009, 5:433-441.

doi:10.1186/ar3348

Cite this article as: Youinou P, Pers JO: Disturbance of cytokine networks in Sjögren's syndrome. Arthritis Research \& Therapy 2011, 13:227. 